Iraqi Journal of Industrial Research (IJOIR)

Journal homepage: http://ijoir.gov.iq

\title{
A Prototype Development and Fabrication: Electricity Generation from Speed Breaker
}

\author{
${ }^{1}$ Syed Hasan Mehdi*, ${ }^{2}$ Rajanikant Arya
}

${ }^{1}$ Director Reliable Hands - India

${ }^{2}$ Alumini Mechanical Engineering Department, Sagar Institute of Technology \& Management - India

\section{Article information \\ Article history: \\ Received: July, 08, 2021 \\ Accepted: August, 26, 2021 \\ Available online: December, 14, 2021}

\section{Keywords:}

Highway Lighting,

Power Generation,

Speed Breaker,

Ratchet Mechanism

\section{*Corresponding Author:}

Syed Hasan Mehdi

syedmehdi072@gmail.com

DOI:

https://doi.org/10.53523/ijoirVol8I3ID57

\begin{abstract}
Electricity is the fundamental need of human society. Any nation's growth depends on energy. The worldwide electricity consumption increases and conventional electricity sources are causing pollution. Therefore, some non-conventional energy recourses are mandatory to be designed and developed for electricity generation, and they are useful and environment-friendly. In this study, a renewable, non-conventional energy source prototype has been developed, based on the mechanism of power generation from speed breaker with ratchet and pawl mechanism. This study aims to convert the kinetic energy of vehicles into electrical energy which can be used for street and highway lighting and conservation of electrical energy.
\end{abstract}

\section{Introduction}

Energy sources like coal, oil and gas come to face challenges such as reduction of fossil fuel reserves, greenhouse gas emission and other environmental concerns. Even though, renewable energy sources are the most useful alternatives and they provide the only solution to the growing challenges [1]. Renewable power sources have so far demonstrated resilience in the face of the Covid-19 crisis. The share of renewable energy in global electricity supply reached nearly $28 \%$ in the first quarter of 2020, up from 26\% during the same period in 2019 [2].

Conventional energy sources like natural gas, oil, coal, and nuclear power plant are predetermined and fixed recourses and widely used all over the world. But renewable energy sources like wind, solar, geothermal, etc. are non-polluting and easily available in nature.

Similarly, producing electricity from speed breaker is not a new concept, various researches and developments have been made in this regard. [3], [4] Every speed breaker can become a source of voltage generation, a vehicle kinetic energy can be converted into rotational energy of roller and produces a considerable amount of energy as shown in Table (1) [5]. 
Table (1). Weight of Vehicle Vs. Voltage Generated [5]

\begin{tabular}{|c|c|}
\hline Load of the vehicle (kg) & Voltage generated (V) \\
\hline 100 & 1.6 \\
\hline 250 & 4.2 \\
\hline 400 & 6.5 \\
\hline 750 & 11.44 \\
\hline 1050 & 17.16 \\
\hline
\end{tabular}

Roller is used as speed breaker in various models of power generation depending on speed breaker but there is a problem in the roller as a speed breaker that when a vehicle passes over it there will be a backward motion. Therefore, in this prototype, a ratchet and pawl mechanism has been introduced for avoiding backward motion in rollers. Electricity generation from speed breaker is a clean and better tool for the conservation of energy.

Electricity generation from speed breaker can be easily explained and understood by comparing it with other power generation sources as shown in Table (2).

Table (2). Comparison with Other Sources of Power Generation

\begin{tabular}{|c|c|c|c|c|}
\hline \multirow[b]{2}{*}{ Parameters } & \multicolumn{4}{|c|}{ Power Generation Sources } \\
\hline & Speed Breaker & Conventional & Solar & Wind \\
\hline Initial Cost & $\begin{array}{l}\text { Lesser as } \\
\text { compared to } \\
\text { others }\end{array}$ & Very high & $\begin{array}{l}\text { Lesser than } \\
\text { thermal, } \\
\text { nuclear and } \\
\text { hydro plants }\end{array}$ & $\begin{array}{c}\text { Lesser } \\
\text { than solar plants }\end{array}$ \\
\hline Fuel Used & No & $\begin{array}{l}\text { Fossil fuel, } \\
\text { nuclear fuel } \\
\text { etc. }\end{array}$ & $\begin{array}{l}\text { No fuel } \\
\text { (sunlight is } \\
\text { utilized) }\end{array}$ & $\begin{array}{c}\text { No fuel } \\
\text { (wind energy) }\end{array}$ \\
\hline $\begin{array}{l}\text { Operating } \\
\text { Cost }\end{array}$ & $\begin{array}{l}\text { Negligible (only } \\
\text { maintenance } \\
\text { cost) }\end{array}$ & High & $\begin{array}{c}\text { Nil for } \\
\text { photovoltaic } \\
\text { cell }\end{array}$ & $\begin{array}{l}\text { Higher than } \\
\text { the speed breaker }\end{array}$ \\
\hline $\begin{array}{c}\text { Renewable } \\
\text { Energy Form }\end{array}$ & Yes & No & Yes & Yes \\
\hline Supply & Steady & $\begin{array}{l}\text { Fuel supply } \\
\text { and load } \\
\text { dependent }\end{array}$ & Fluctuating & Fluctuating \\
\hline $\begin{array}{c}\text { Transmission } \\
\text { Cost and } \\
\text { Losses } \\
\end{array}$ & Low & High & Low & High \\
\hline $\begin{array}{l}\text { Cost Per Unit } \\
\text { of Energy }\end{array}$ & $\begin{array}{l}\text { High for small } \\
\text { units but would } \\
\text { prove cost } \\
\text { effective for wider } \\
\text { network and on } \\
\text { long term basis }\end{array}$ & $\begin{array}{l}\text { Less at present } \\
\text { but would } \\
\text { increase } \\
\text { rapidly due to } \\
\text { depletion of } \\
\text { fuel resources }\end{array}$ & Less & Less \\
\hline
\end{tabular}




\begin{tabular}{|c|c|c|c|c|}
\hline $\begin{array}{c}\text { Time } \\
\text { Required for } \\
\text { Power } \\
\text { Generation }\end{array}$ & Less & More & Very less & Less \\
\hline Reliability & $\begin{array}{c}\text { Reliable due to } \\
\text { regular traffic } \\
\text { movement }\end{array}$ & $\begin{array}{c}\text { Reliable long } \\
\text { as fuel is } \\
\text { available }\end{array}$ & $\begin{array}{c}\text { Less reliable } \\
\text { (sunlight } \\
\text { dependent) }\end{array}$ & $\begin{array}{c}\text { Less reliable due to } \\
\text { wind variation }\end{array}$ \\
\hline Pollution & $\begin{array}{c}\text { Pollution free } \\
\text { energy generation } \\
\text { atmospheric } \\
\text { and water } \\
\text { pollution }\end{array}$ & $\begin{array}{c}\text { Pollution } \\
\text { free energy } \\
\text { generation }\end{array}$ & $\begin{array}{c}\text { Pollution free energy } \\
\text { generation }\end{array}$ \\
\hline Future Scope & $\begin{array}{c}\text { Great scope for } \\
\text { small } \\
\text { especially in new } \\
\text { establishment } \\
\text { infrastructures in } \\
\text { high tech cities }\end{array}$ & $\begin{array}{c}\text { Limited due to } \\
\text { depleting fossil } \\
\text { fuels }\end{array}$ & $\begin{array}{c}\text { Wide scope } \\
\text { as huge } \\
\text { amount of } \\
\text { solar energy } \\
\text { is available }\end{array}$ & $\begin{array}{c}\text { Lesser than solar and } \\
\text { speed as wind sites are } \\
\text { only selected and it } \\
\text { cannot be created }\end{array}$ \\
\hline
\end{tabular}

\section{Experimental Procedure}

\subsection{Working Principle}

The number of vehicles on road is increasing rapidly and if the kinetic energy of these vehicles is converted into the rotational motion of the roller then a considerable amount of electricity will be produced, this is the main concept of this study. In the present prototype, rollers are fitted in between a speed breaker and some kind of a grip is provided on the speed breaker so that when a vehicle passes over the speed breaker it rotates the roller. This movement of roller is used to rotate the shaft of the D.C. generator with the help of chain drive which is there to provide 1:5 speed ratios. A flywheel is also attached to the shaft of the smaller sprocket to get an uninterrupted rotation of the shaft and thus the generator. As the shaft of the D.C. generator rotates, it produces electricity. This electricity is stored in a battery. Then the output of the battery is used to lighten the street and highway lighting on the road. Now during the daytime, there is no need for electricity to lightening the street lamps so a control switch may be used for ON/ OFF. The control switch is connected by wire to the output of the battery. The control switch has ON/OFF mechanism which allows the current to flow when needed. The complete mechanism of electricity generation is shown in figure 1.

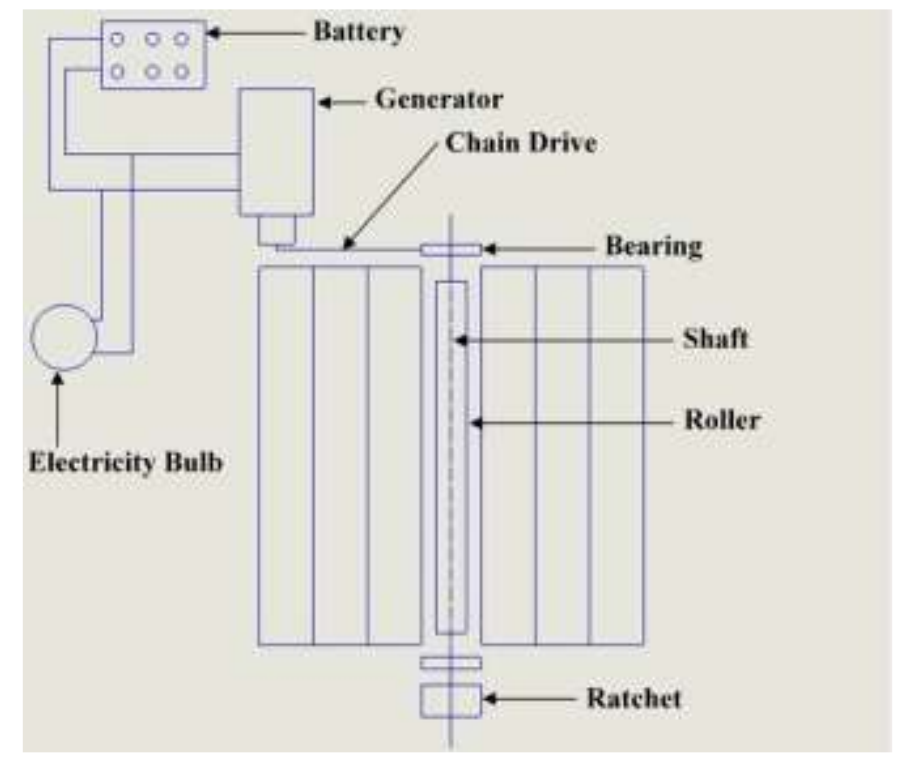

Figure (1). Line Diagram of Electricity Generation from Speed Breaker. 


\subsection{Ratchet and Pawl Mechanism}

When vehicle wheels pass over the roller then backward motion takes place instead of complete forwarding motion. To overcome this problem a ratchet pawl mechanism was introduced in this prototype. Three-dimensional design simulation of ratchet pawl mechanism designed in Solidworks Designing Software as shown in figure 2, and applied in prototype as shown in figure 3.

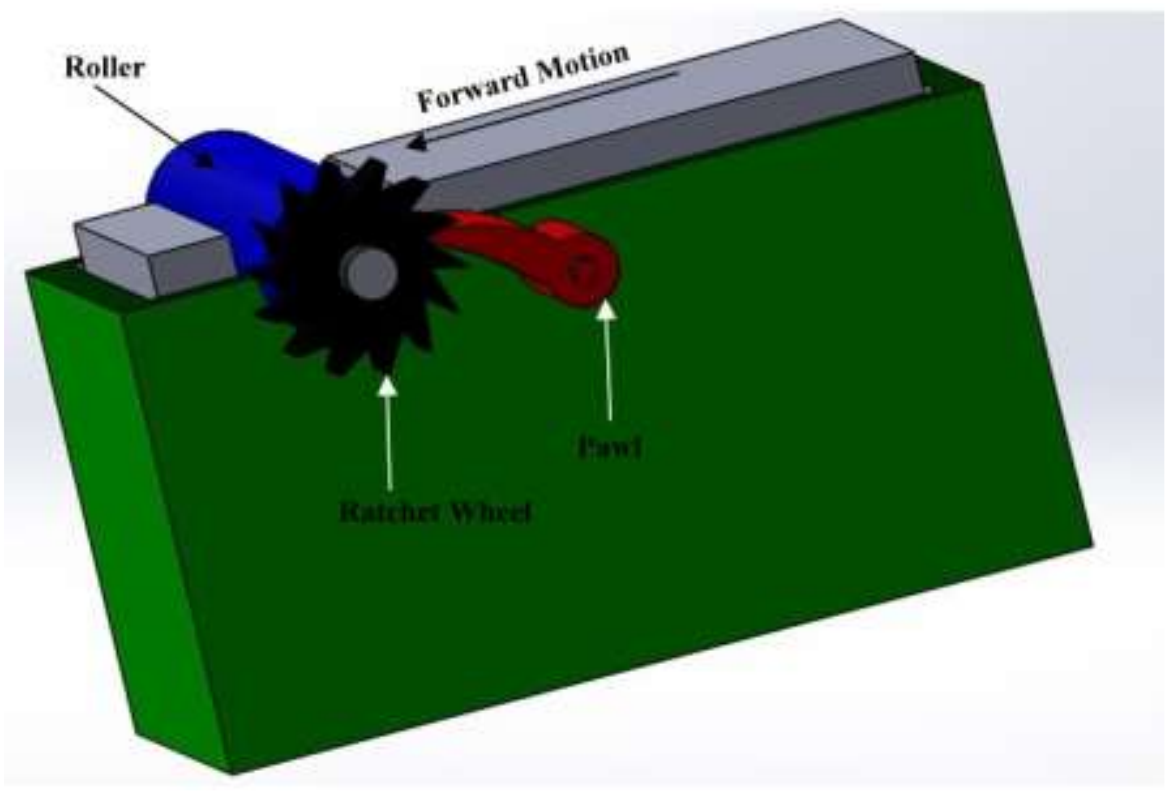

Figure (2). Ratchet and Pawl Mechanism.

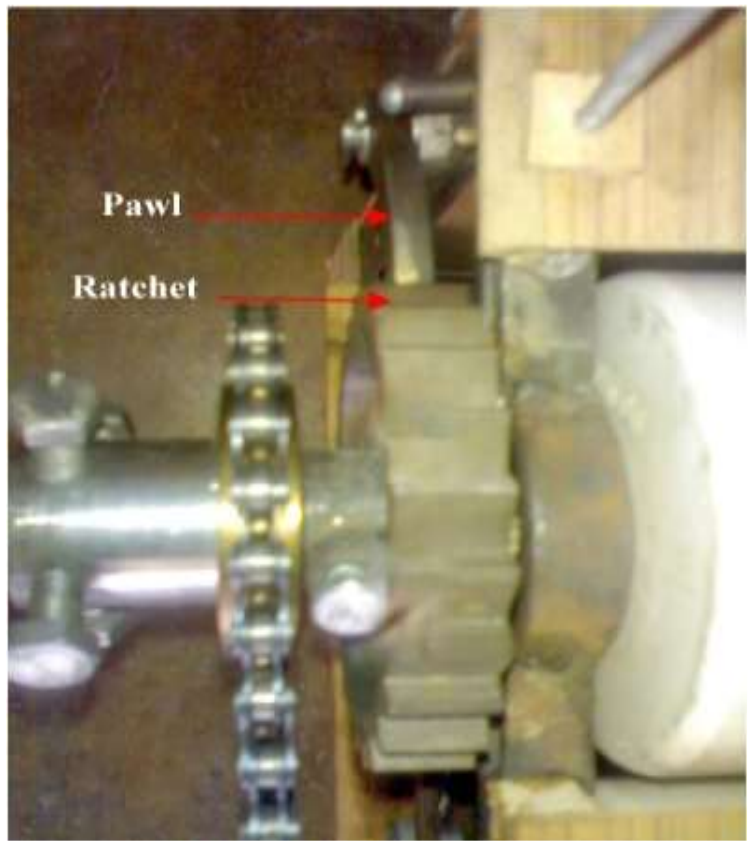

Figure (3). Ratchet and Pawl in Prototype. 


\subsection{Fabrication of Prototype}

The components used in prototype fabrication were Rollers, Shafts, Roller bearings, Dynamo, Chain \& sprockets, Flywheels, Rubber cord, LED lights, Wires for electrical connections, Cast iron casing, 9V relay coil, Screws, Wooden covering, Grease to reduce friction and Ratchet wheel \& Pawl. Wires are connected to the terminal of generator and other ends to the battery and output wire is connected to the light bulbs. The complete prototype arranged system of electricity generation is shown in figure 4 .

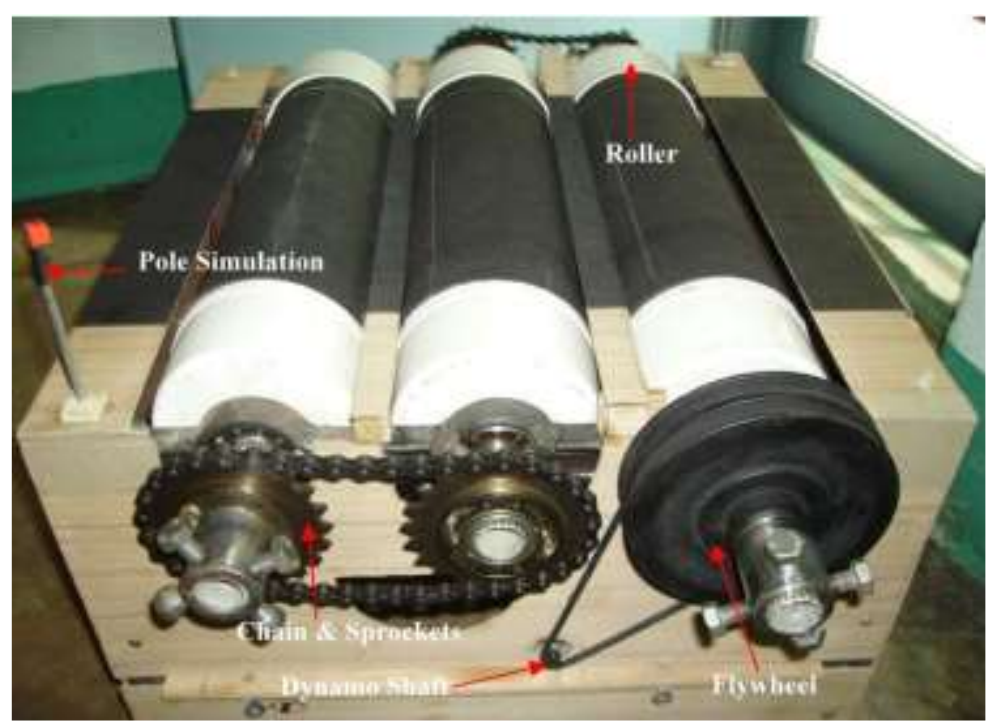

Figure (4). Prototype of Electricity Generation from Speed Breaker.

\section{Results and Discussion}

The present study aimed to overcome backward motion of roller by ratchet mechanism and conversion of the kinetic energy of vehicle to electrical energy. The kinetic energy of the vehicle is converted to rotational energy of roller. These circular motions are transferred to the generator by an arranged transmission system.

\section{Output Power Calculation}

The mass of a vehicle moving over the speed breaker $=20 \mathrm{~kg}$

Height of speed breaker above ground level $=7 \mathrm{~cm}$

Work done $=$ Force $\mathrm{x}$ Distance

Force $=$ Weight of the Body Force $=20 \mathrm{~kg} \mathrm{x} 9.81 \mathrm{~m} / \mathrm{s}^{2}$ (acceleration due to gravity)

Force $=196.2 \mathrm{~N}$

Distance travelled by the body $=$ Height of roller above ground level $=7 \mathrm{~cm}$

Output power $=$ Work done $/ \mathrm{Sec}=(196.2 \times 0.07) / 60=0.2289$ watt

Power developed for $20 \mathrm{~kg}$ vehicle passing over the speed breaker arrangement for one minute $=0.2289 \mathrm{watt}$

Power Developed for different load vehicles over speed breaker in one minute is shown in table 3.

Table (3). Vehicle Load Vs. Power Developed

\begin{tabular}{|c|c|}
\hline Vehicle Load (kg) & Power Developed (W) \\
\hline 200 & 2.289 \\
\hline 250 & 2.861 \\
\hline 300 & 3.433 \\
\hline 350 & 4.005 \\
\hline 400 & 4.578 \\
\hline
\end{tabular}

The demand for energy supply is increasing all over the world. The requirement achieves in an eco-friendly way is a tough task. There are many problems in the production of electrical energy. Renewable energy sources are better tools for power generation. In this regard, solar and wind energy sources have been successfully producing electrical energy. 
Cycling pedaling can also be a source of power generation, which is eco-friendly and a form of renewable energy source. There would be various applications of pedaling power generation like Pedal-powered laptops, Pedalpowered washing machines, Pedal-powered water pumps, Pedal-powered lawnmowers, Pedal-powered refrigerators, etc. [6]

Similarly, electricity generation from speed breakers is also a renewable energy source, which can produce a considerable amount of electricity. There are various models which have been introduced in this regard, but electricity generation from speed breaker has not been adopted by human society.

Generally, in cities and highways a road divider is used for dividing ongoing and incoming traffic. [7] The power generation from the speed breaker can be installed at both sides of the divider and utilized the vehicle kinetic energy to rotate the generator shaft. If any vehicle came from the wrong/ other direction then it will be treated as a simple speed breaker.

\section{Conclusions}

Nowadays almost every city in the world is flooded with automobiles. The wasted kinetic energy of vehicles at speed breakers can be utilized for power generation. The main aim of this prototype was rotation of dynamo shaft with respect to rotation of rollers. The findings of this study were the conversion of the kinetic energy of vehicles into the rotational motion of rollers with ratchet and pawl mechanism which avoided backward motion. This rotation of rollers causes rotation of generator shaft which can produce a considerable amount of electricity. This generated energy can be stored with the help of batteries. On the basis of this prototype fabrication, the following conclusions have been made:

1. It has been observed that there is no backward motion of rollers with a ratchet mechanism.

2. The rotational energy of rollers is converted into the rotational energy of the dynamo shaft.

3. It is pollution-free energy conversion.

4. It is a form of renewable energy resource.

5. The number of rollers can be increased for more power generation.

Thus the energy generated from speed breakers can be utilized in streets and highways lighting, providing electricity to stores and residual areas and for operating electric motors, etc.

Acknowledgement: This work was supported by the Workshop of Mechanical Engineering Department, Sagar Institute of Technology \& Management, Barabanki, INDIA. The authors wish to pay their gratitude to Prof. D.P. Singh for his supervision. The authors would like to thank Prof. J.K. Jauhari for his technical suggestions, and both Er. Vijay Singh and Er. Sudhir Tripathi for their contribution to the fabrication of this prototype.

\section{References}

[1] Phebe Asantewaa Owusu and Samuel Asumadu-Sarkodie, "A review of renewable energy sources, sustainability issues and climate change mitigation," Cogent Engineering, vol. 3, p. 1-14, 2016.

[2] IEA (2020), "The impact of the Covid-19 crisis on clean energy progress", IEA, Paris https://www.iea.org/articles/the-impact-of-the-covid-19-crisis-on-clean-energy-progress

[3] Y.Siva Mallesh , P. Santosh Kumar, G. Ravi Teja, B. Sanjay, et al., "A Detailed study on Power Generation using Speed Breakers," International Journal of Innovative Science and Research Technology, vol. 6, p. 1146-1150, 2021.

[4] Manoj Kumar, K. N. S. Rahul, Malathi Narra, B. Pandu RangaRao, et al., "Efficient Method on Energy Regeneration through Speed Breakers," International Journal of Innovative Technology and Exploring Engineering, vol. 9, p. 19-23, 2020.

[5] N. N. Ghuge, Arati Sathe, Varsha Patil, Anagha Warankar, et al., "Every Speed Breaker Is A Source of Power," International Journal of Engineering Research and Applications, vol. 4, p. 01-05, 2014.

[6] Rajesh Kannan Megalingam, Pranav Sreedharan Veliyara, Raghavendra Murali Prabhu, Rocky Katoch, et al., "Pedal Power Generation," International Journal of Applied Engineering Research, vol. 7, p. 1473-1477, 2012.

[7] B. D. Sri, K. Nirosha and S. Gouse, "Design and implementation of smart movable road divider using IOT,” International Conference on Intelligent Sustainable Systems, p. 1145-1148, 2017. 